\title{
Lack of PIVKA effect in the abnormal factor $X$ (factor $X$ friuli) coagulation disorder
}

Citation for published version (APA):

Girolami, A., Muller, A. D., \& Hemker, H. C. (1972). Lack of PIVKA effect in the abnormal factor X (factor X friuli) coagulation disorder. Haemostasis, 1(1), 23-30. https://doi.org/10.1159/000213735

Document status and date:

Published: 01/01/1972

DOI:

10.1159/000213735

Document Version:

Publisher's PDF, also known as Version of record

\section{Please check the document version of this publication:}

- A submitted manuscript is the version of the article upon submission and before peer-review. There can be important differences between the submitted version and the official published version of record.

People interested in the research are advised to contact the author for the final version of the publication, or visit the DOI to the publisher's website.

- The final author version and the galley proof are versions of the publication after peer review.

- The final published version features the final layout of the paper including the volume, issue and page numbers.

Link to publication

\footnotetext{
General rights rights.

- You may freely distribute the URL identifying the publication in the public portal. please follow below link for the End User Agreement:

www.umlib.nl/taverne-license

Take down policy

If you believe that this document breaches copyright please contact us at:

repository@maastrichtuniversity.nl

providing details and we will investigate your claim.
}

Copyright and moral rights for the publications made accessible in the public portal are retained by the authors and/or other copyright owners and it is a condition of accessing publications that users recognise and abide by the legal requirements associated with these

- Users may download and print one copy of any publication from the public portal for the purpose of private study or research.

- You may not further distribute the material or use it for any profit-making activity or commercial gain

If the publication is distributed under the terms of Article $25 \mathrm{fa}$ of the Dutch Copyright Act, indicated by the "Taverne" license above, 


\title{
Lack of PIVKA Effect in the Abnormal Factor X (Factor X Friuli) Coagulation Disorder
}

\author{
A. Girolami, A.D. Muller and H.C. Hemker \\ Laboratories of Cardiovascular Biochemistry and Blood Coagulation Biochemistry, \\ University Hospital, Leiden
}

\begin{abstract}
Thrombotest dilution curves and specific Key Words inhibitor experiments were carried out in the abnormal Factor X Friuli factor X (factor X Friuli) plasma and in coumarin plasma. PIVKA effect Thrombotest dilution curves obtained with Friuli plasma Coumarin-induced inhibition suggested the presence of a PIVKA-like inhibitor which Thrombotest was not confirmed by the specific experiments. The inhibitory capacity found in Friuli plasma was -0.09 arbitrary units, whereas that found in coumarin-treated patients with a factor $\mathrm{X}$ level ranging from 1 to $14 \%$ varied between 0.34 and 0.21 arbitrary units.
\end{abstract}

The occurrence of a blood coagulation inhibiting protein in the plasma of patients treated with anticoagulants was first suspected on the observation that the levels of factors II, VII and X as determined in specific assays did not correspond to those obtained in the thrombotest system [12, 15]. This hypothesis was confirmed later on the basis of kinetic experiments. The action of this protein can be explained by admitting it to act as an analogue of normal coagulation factors [14]. It was postulated that the inhibitor consists of precursors which cannot be converted into the normal factors because a final vitamin K-dependent step in their synthesis is blocked. The existence of such proteins induced by vitamin $K$ absence (PIVKAs) was demonstrated recently by immunological methods [18-20].

The abnormal factor X (factor X Friuli) coagulation disorder was first described in 1969 and $1970[4,5]$. This abnormal factor X cannot be activated or it can be activated only very slowly by partial or whole tissue thromboplastin, whereas it can still be normally activated by Russell's viper venom

Received: November 21, 1972; accepted: November 27, 1972. 
(RVV). As a consequence factor $\mathrm{X}$ results to be low only when assayed using whole or partial tissue thromboplastin; if factor $\mathrm{X}$ is assayed according to the method of BACHMANN et al. [1] and Denson [2] it results to be normal or near normal.

The name 'Friuli' was attached to the conditions since all the patients originally described to have this disorder came from an isolated valley in the northeastern Italian region called 'Friuli' $[5,6]$. On theoretical grounds, it could be speculated that this congenitally determined abnormality could have some similarities with the coumarin-induced abnormal form.

These considerations and the observation of an inhibitory type of thrombotest dilution curve for the Friuli plasma prompted this report.

\section{Material and Methods}

Friuli plasma was obtained in Padova from one of the patients known to have this disorder (patient M.P.) [5]. The platelet-free citrated plasma was stored in plastic tubes at $-20^{\circ} \mathrm{C}$ in $5 \mathrm{ml}$ aliquots and brought to Leiden frozen. In these studies we used plasma samples drawn on four different dates (16.11.1971, 14.12.1971, 4.2.1972 and 12.10.1972).

The factor X content in the frozen Friuli plasma as determined in Leiden with human brain thromboplastin was $6.8 \%$ of normal. This was in good agreement with the results obtained in Padova for the same patient on fresh plasma $[5,8]$. The mean factor II, factor V and factor VII levels in frozen Friuli plasma samples were 64.4, 132.2 and $77.8 \%$, respectively, in good agreement with the values obtained in Padova on fresh plasma [5], and within the limits found in plasma from normal persons.

Platelet-free citrated normal plasma was obtained from 30 healthy persons, aged about 30 years, and stored in plastic tubes at $-20^{\circ} \mathrm{C}$ in $10 \mathrm{ml}$ aliquots.

Platelet-free plasma of an overanticoagulated patient (attempted suicide). The factor X content in this plasma was about $1 \%$ of normal, whereas its factor II, V and VII content was 1,64 and $1 \%$, respectively [14].

Human brain thromboplastin, batch 1926 Leiden, was prepared according to a modification of the method of OWREN and AAs [17]. Factor X reagent was prepared as previously reported [16]. The batch used (batch No.1110) contained $0.98 \%$ factor X.

'Fake' Friuli plasma was prepared by mixing 6 parts of normal plasma with 94 parts of factor $\mathrm{X}$ reagent. The factor $\mathrm{X}$ content was $11.0 \%$, whereas factors II, V, and VII were $22.8,60.6$ and $41.6 \%$, respectively.

'Fake' coumarin plasma was prepared by mixing 99 parts of $\mathrm{Al}(\mathrm{OH})_{3}$ adsorbed normal plasma with 1 part of normal plasma. The factor II, VII, and X content of this 'fake' plasma was $1 \%$ of normal.

Thrombotest dilution tests were carried out with $1: 1,1: 2,1: 3,1: 5$ and $1: 10$ Michaelis buffer diluted Friuli plasma, coumarin plasma and normal plasma. Thrombotest reagent was supplied by Nyegaard Laboratories, Oslo (Batch 123). The investigation of specific inhibition by Friuli plasma was carried out as previously reported [14]. Normal plasma 
was diluted $1: 1,1: 2,1: 3,1: 4,1: 5,1: 6,1: 7,1: 8,1: 9$, and $1: 10$ in factor $\mathrm{X}$ reagent. These dilutions were kept in plastic tubes at $0{ }^{\circ} \mathrm{C}$. Then to a $0.075-\mathrm{ml}$ aliquot of each of such dilutions $0.025 \mathrm{ml}$ Friuli plasma or 'fake' Friuli plasma were added. In the case of coumarin plasma or 'fake' coumarin plasma, the volumes were $0.05 \mathrm{ml}$ each. Eventually factor $\mathrm{X}$ was assayed in all mixtures by means of a one-stage method using human brain thromboplastin. Clotting times were then plotted against the inverse of factor $\mathrm{X}$ concentration. In such a curve a competitive inhibitor causes the straight line giving $t_{c}$ as a function of $1 /(x)$ to become steeper, maintaining the same interaction with the ordinate. Thus, the same $t_{\min }$ is read as with the inhibitor present, but a different $\mathrm{K}_{\mathrm{m}}$ is found.

The inhibitory capacity of the plasma tested can be assessed from the curves obtained by calculating the ratio $\mathrm{K}_{\mathrm{m}}^{\prime} / \mathrm{K}_{\mathrm{m}}, \mathrm{K}_{\mathrm{m}}$ being the Michaelis constant of the uninhibited series and $\mathrm{K}_{\mathrm{m}}^{\prime}$ the apparent $\mathrm{K}_{\mathrm{m}}$ of the inhibited series.

As $\mathrm{K}_{\mathrm{m}}^{\prime}=\mathrm{K}_{\mathrm{m}}\left(1+\frac{\mathrm{i}}{\mathrm{k}_{\mathrm{i}}}\right) \quad \mathrm{I}=\frac{\mathrm{i}}{\mathrm{k}_{\mathrm{i}}}=\frac{\mathrm{K}_{\mathrm{m}}^{\prime}}{\mathrm{K}_{\mathrm{m}}}-1, \mathrm{k}_{\mathrm{i}}$ being the unknown constant. This is the closest we can get to quantitate $c_{i}$, i.e. the concentration of the inhibitor.

\section{Results}

The results of thrombotest dilution studies are reported in figure 1 . The Friuli plasma dilution curve as well as the coumarin plasma dilution curve obtained with the (aspecific) thrombotest reagent do not meet the $\mathrm{Y}$-axis at the same point as the normal plasma dilution curve does. This would seem to indicate the presence of an inhibitor and prompted us to try and find inhibition in specific experiments where only the concentration of factor $\mathrm{X}$ is varied. Such inhibition can be demonstrated to occur in coumarin plasma [14].

The specific experiments are summarized in table I and II, and in figures 2 and 3. No inhibitory effect seems present in Friuli plasma since the clotting times obtained at equivalent factor $\mathrm{X}$ concentrations are practically identical to those obtained for the 'fake' Friuli plasma (inhibitory capacity: $I=-0.09$ ). On the contrary, in the case of the overanticoagulated plasma, a clear inhibitory effect was present. At equivalent factor $\mathrm{X}$ concentrations the clotting times were longer than those obtained for the 'fake' coumarin plasma. These data are in agreement with the results obtained in other patients given coumarin-like drugs for therapeutic purposes. In a series of coumarin plasmas the inhibitory capacity I varied between 0.39 and 0.29 without any apparent correlation with the concentration of factor $\mathrm{X}$ (which varied between 1 and $14 \%$ ). 
was diluted $1: 1,1: 2,1: 3,1: 4,1: 5,1: 6,1: 7,1: 8,1: 9$, and $1: 10$ in factor $\mathrm{X}$ reagent. These dilutions were kept in plastic tubes at $0{ }^{\circ} \mathrm{C}$. Then to a $0.075-\mathrm{ml}$ aliquot of each of such dilutions $0.025 \mathrm{ml}$ Friuli plasma or 'fake' Friuli plasma were added. In the case of coumarin plasma or 'fake' coumarin plasma, the volumes were $0.05 \mathrm{ml}$ each. Eventually factor $\mathrm{X}$ was assayed in all mixtures by means of a one-stage method using human brain thromboplastin. Clotting times were then plotted against the inverse of factor $\mathrm{X}$ concentration. In such a curve a competitive inhibitor causes the straight line giving $t_{c}$ as a function of $1 /(x)$ to become steeper, maintaining the same interaction with the ordinate. Thus, the same $t_{\min }$ is read as with the inhibitor present, but a different $\mathrm{K}_{\mathrm{m}}$ is found.

The inhibitory capacity of the plasma tested can be assessed from the curves obtained by calculating the ratio $\mathrm{K}_{\mathrm{m}}^{\prime} / \mathrm{K}_{\mathrm{m}}, \mathrm{K}_{\mathrm{m}}$ being the Michaelis constant of the uninhibited series and $\mathrm{K}_{\mathrm{m}}^{\prime}$ the apparent $\mathrm{K}_{\mathrm{m}}$ of the inhibited series.

$$
\text { As } \mathrm{K}_{\mathrm{m}}^{\prime}=\mathrm{K}_{\mathrm{m}}\left(1+\frac{\mathrm{i}}{\mathrm{k}_{\mathrm{i}}}\right) \quad \mathrm{I}=\frac{\mathrm{i}}{\mathrm{k}_{\mathrm{i}}}=\frac{\mathrm{K}_{\mathrm{m}}^{\prime}}{\mathrm{K}_{\mathrm{m}}}-1, \mathrm{k}_{\mathrm{i}} \text { being the unknown constant. }
$$

This is the closest we can get to quantitate $c_{i}$, i.e. the concentration of the inhibitor.

\section{Results}

The results of thrombotest dilution studies are reported in figure 1 . The Friuli plasma dilution curve as well as the coumarin plasma dilution curve obtained with the (aspecific) thrombotest reagent do not meet the Y-axis at the same point as the normal plasma dilution curve does. This would seem to indicate the presence of an inhibitor and prompted us to try and find inhibition in specific experiments where only the concentration of factor $\mathrm{X}$ is varied. Such inhibition can be demonstrated to occur in coumarin plasma [14].

The specific experiments are summarized in table I and II, and in figures 2 and 3. No inhibitory effect seems present in Friuli plasma since the clotting times obtained at equivalent factor $\mathrm{X}$ concentrations are practically identical to those obtained for the 'fake' Friuli plasma (inhibitory capacity: $I=-0.09$ ). On the contrary, in the case of the overanticoagulated plasma, a clear inhibitory effect was present. At equivalent factor $\mathrm{X}$ concentrations the clotting times were longer than those obtained for the 'fake' coumarin plasma. These data are in agreement with the results obtained in other patients given coumarin-like drugs for therapeutic purposes. In a series of coumarin plasmas the inhibitory capacity I varied between 0.39 and 0.29 without any apparent correlation with the concentration of factor $\mathrm{X}$ (which varied between 1 and $14 \%$ ). 


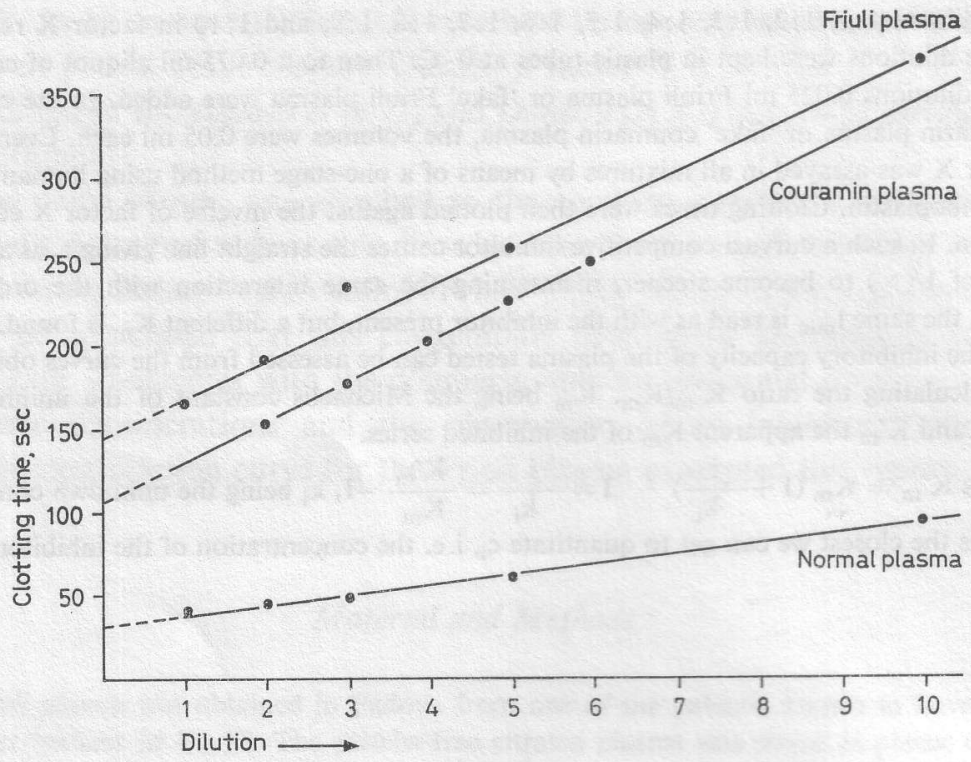

Fig.1. Thrombotest dilution curve with normal plasma, Friuli plasma and coumarintreated plasma. The extrapolations of the Friuli plasma and coumarin plasma curves to the $\mathrm{Y}$-axis do not meet with the extrapolation of the normal curve. The coumarin plasma used in this experiment had a factor X content of $14 \%$, whereas factor II, V and VII were 21, 100 and $22 \%$, respectively. Using the overanticoagulated plasma, no curve could be constructed because of the extremely prolonged or infinite clotting times obtained.

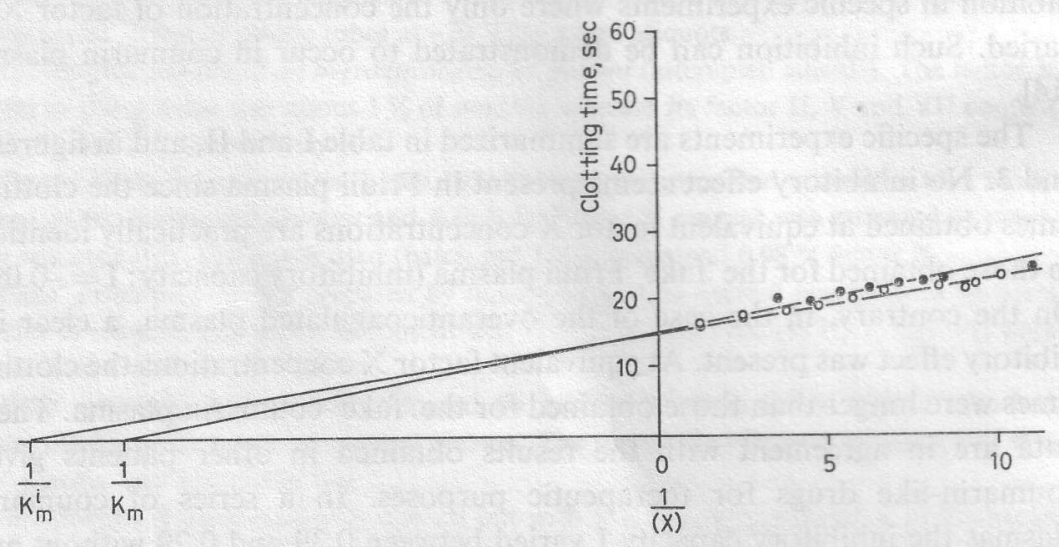

Fig. 2. Lack of PIVKA effect in Friuli plasma. No difference is evident between Friuli plasma (O) and 'fake' Friuli plasma ( ). Inhibitory capacity $I=-0.09$. 


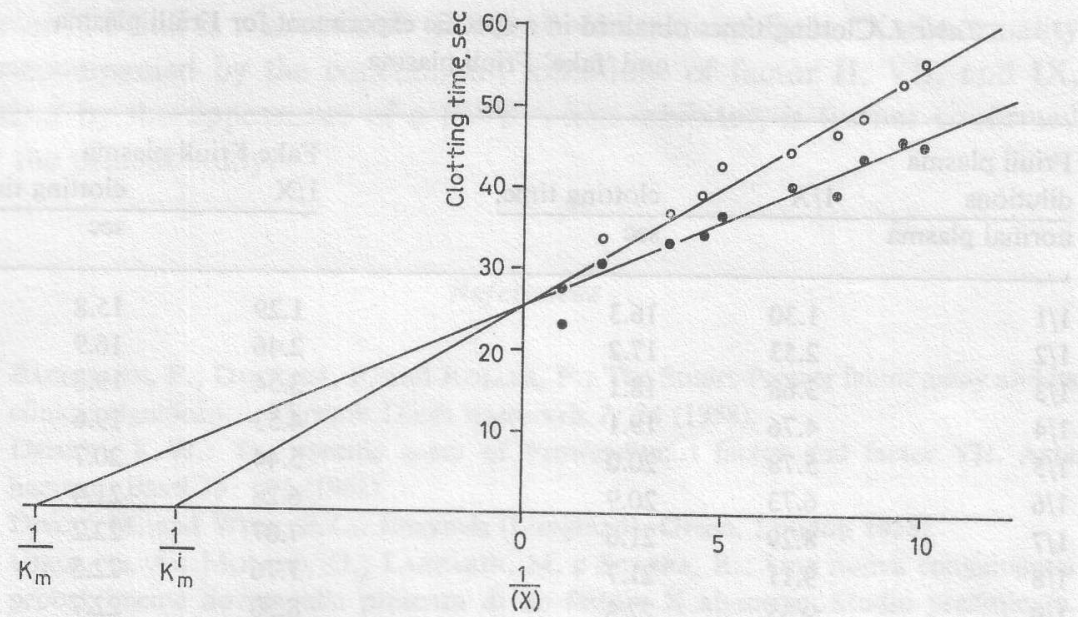

Fig.3. Behaviour of the overanticoagulated plasma in the specific PIVKA experiment. At comparable factor $\mathrm{X}$ concentrations clotting times are longer in coumarin plasma $(\mathrm{O})$ as compared to 'fake' coumarin plasma ( ) . Inhibitory capacity $I=0.39$.

\section{Discussion}

Our data indicate that in Friuli plasma no inhibitory effect is present. The congenitally abnormal factor $\mathrm{X}$ and the abnormal factor $\mathrm{X}$ induced by vitamin $\mathrm{K}$ absence do not seem to behave similarly in a coagulation system. This is the more interesting as there exists a congenital factor II abnormality (prothrombin Barcelona) which up till now has appeared identical to the abnormal prothrombin induced by vitamin $\mathrm{K}$ absence [21].

The results of the kinetic studies are in agreement with immunological data [9]. In a cross-over electrophoresis or electrosyneresis system using antihuman factor $\mathrm{X}$ rabbit antiserum it could be demonstrated that coumarin plasma has two factor $\mathrm{X}$ bands [9]. One of these bands is equivalent to the normal factor $\mathrm{X}$ band, the second one, slightly more cathodic to it, is typical of anticoagulated plasma. In Friuli plasma only an apparently normal factor $\mathrm{X}$ band is visible.

All these data seem to indicate that factor X Friuli is different from the coumarin-induced abnormal form. The obvious discrepancy between the thrombotest dilution studies (fig.1) and the specific experiment (fig.2) is probably due to the fact that in a single factor deficiency or abnormality the dilution curve approach to the problem is of no value. It is known, in fact, that factor II, VII, and IX activities are normal in Friuli plasma [5-7]. 
Table I. Clotting times obtained in a specific experiment for Friuli plasma and 'fake' Friuli plasma

\begin{tabular}{|c|c|c|c|c|}
\hline \multirow{3}{*}{$\begin{array}{l}\text { Friuli plasma } \\
\text { dilutions } \\
\text { normal plasma }\end{array}$} & \multirow{3}{*}{$1 / \mathrm{X}$} & \multirow{3}{*}{$\frac{\text { clotting time, }}{\text { sec }}$} & \multicolumn{2}{|c|}{ Fake Friuli plasma } \\
\hline & & & $1 / \mathrm{X}$ & clotting time, \\
\hline & & & & $\mathrm{sec}$ \\
\hline $1 / 1$ & 1.30 & 16.3 & 1.29 & 15.8 \\
\hline $1 / 2$ & 2.53 & 17.2 & 2.46 & 16.9 \\
\hline $1 / 3$ & 3.68 & 18.1 & 3.54 & 19.8 \\
\hline $1 / 4$ & 4.76 & 19.1 & 4.53 & 19.6 \\
\hline $1 / 5$ & 5.78 & 20.0 & 5.44 & 20.7 \\
\hline $1 / 6$ & 6.73 & 20.9 & 6.28 & 21.4 \\
\hline $1 / 7$ & 8.29 & 21.6 & 7.07 & 22.2 \\
\hline $1 / 8$ & 9.11 & 21.7 & 7.76 & 22.5 \\
\hline $1 / 9$ & 9.35 & 22.3 & 8.50 & 22.7 \\
\hline $1 / 10$ & 10.12 & 23.0 & 11.16 & 23.5 \\
\hline
\end{tabular}

Table II. Clotting times obtained in a specific experiment for coumarin plasma and 'fake' coumarin plasma

\begin{tabular}{llllll}
\hline \multirow{2}{*}{$\begin{array}{l}\text { Coumarin plasma } \\
\text { dilutions }\end{array}$} & $1 / \mathrm{X}$ & \multicolumn{2}{c}{ clotting time, } & & \multicolumn{2}{c}{$\begin{array}{l}\text { Fake coumarin plasma } \\
\text { clotting time, }\end{array}$} \\
\cline { 1 - 3 } normal plasma & & sec & & sec \\
\cline { 5 - 6 } $1 / 1$ & 1.00 & 27.4 & 1.00 & 25.4 \\
$1 / 2$ & 2.00 & 33.4 & 2.00 & 30.2 \\
$1 / 3$ & 3.70 & 36.4 & 3.70 & 33.7 \\
$1 / 4$ & 4.50 & 39.1 & 4.50 & 34.0 \\
$1 / 5$ & 5.00 & 42.6 & 5.00 & 36.5 \\
$1 / 6$ & 6.67 & 44.4 & 6.67 & 40.1 \\
$1 / 7$ & 7.85 & 46.6 & 7.85 & 39.1 \\
$1 / 8$ & 8.50 & 48.4 & 8.50 & 43.3 \\
$1 / 9$ & 9.45 & 52.3 & 9.45 & 45.4 \\
$1 / 10$ & 10.00 & 55.1 & 10.00 & 44.8 \\
\hline
\end{tabular}

These observations are also in further agreement with the observation that the factor X level in Friuli plasma as estimated from the thrombotest system is practically identical to the level obtained with human brain thromboplastin, namely $5-10 \%$ of normal $[8,11]$. The assumption that 
factor X Friuli is a structural, genetically determined factor X abnormality unaccompanied by the concomitant mutations of factor II, VII, and IX, and/or by the appearance of a PIVKA-like inhibitor, is further confirmed by the present study.

\section{References}

1 Bachmann, F.; Duckert, F. and Koller, F.: The Stuart-Prower factor assay and its clinical significance. Thromb. Diath.haemorrh. 2: 24 (1958).

2 Denson, K.W.: The specific assay of Prower-Stuart factor and factor VII. Acta haemat., Basel 25: 105 (1961).

3 Dixon, M. and WebB, E.C.: Enzymes (Longmans, Green, London 1958).

4 Girolami, A.; Molaro, G.; Lazzarin, M. e Scarpa, R.: Una nuova coagulopatia probabilmente dovuta alla presenza di un fattore $\mathrm{X}$ abnorme. Studio preliminare. Minerva med.60: 4939 (1969).

5 Girolami, A.; Molaro, G.; Lazzarin, M.; Scarpa, R., and Brunetti, A.: A 'new' congenital haemorrhagic condition due to the presence of an abnormal factor $\mathrm{X}$ (factor X Friuli). A study of large kindred. Brit. J. Haemat. 19: 179 (1970).

6 Girolami, A.; Lazzarin, M.; Brunetti, A., and ScarPa, R.: Further studies on the abnormal factor X (factor X Friuli) coagulation disorder. A report of another family. Blood 37: 534 (1971).

7 Girolami, A.; Sticchi, A., and Brunetti, A.: Prothrombin level and activity in the abnormal factor X (factor X Friuli) hemorrhagic disorder. Thromb. Diath. haemorrh. 25: 147 (1971).

8 Girolami, A.; Molaro, F. and Lazzarin, M.: The effect of several tissue thromboplastins on the activation of the abnormal factor X (factor X Friuli). Thromb. Diath. haemorrh.27: 535 (1972).

9 Girolami, A.; Bareggi, G., and Fioretti, A.: Different cross-over electrophoresis (electrosyneresis) mobility of abnormal factor X (factor X Friuli) and coumarininduced abnormal factor X. Haemostasis (in press).

10 Girolami, A.; Sticchi, A., and BAREgGi, G.: Cross-over electrophoresis (electrosyneresis) visualization of abnormal factor X (factor X Friuli). J.Lab.clin. Med. 80; 740 (1972).

11 Girolami, A.; Brunetti, A., and Bareggi, G.: Unpublished observations.

12 Hemker, H.C.; Veltkamp, J.J.; Hensen, A., and Loeliger, E.A.: Nature of prothrombin biosynthesis: preprothrombinaemia in vitamin K deficiency. Nature 200: 589 (1963).

13 Hemker, H.C.; VeltKamp, J.J., and Loeliger, E.A.: Kinetic aspects of the interaction of blood clotting enzymes. III. Demonstration of the existence of an inhibitor of prothrombin conversion in vitamin K deficiency. Thromb. Diath.haemorrh. 19: 346 (1968).

14 Hemker, H.C. and Muller, A.D.: Kinetic aspects of the interaction of blood clotting enzymes. VI. Localization of the site of blood coagulation inhibition by the proteins induced by vitamin K absence (PIVKA). Thromb. Diath. haemorrh. 20: 78 (1968). 
15 Hemker, H.C.: Les protéines dont la synthèse est induite par l'avitaminose K. Nouv. Rev. franç. Hémat. 10: 645 (1970).

16 Hemker, H. C.; SWart, A. C. W., and AlinK, A. J. M.: Artificial reagents for factor VII and factor X; a computer program for obtaining reference tables for one-stage determinations in the extrinsic system. Thromb. Diath.haemorrh. 27: 205 (1972).

17 OWREN, P.A. and AAs, K.: The control of dicumarol therapy and the quantitative determination of prothrombin and proconvertin. Scand.J.Lab.Invest. 3: 201 (1951).

18 Josso, F.; Lavergne, J.M.; Gouault, M.; Prou-Wartelle, O. et Soulier, J.P.: Différents états moléculaires du facteur II (prothrombine). Leur étude à l'aide de la staphylocoagulase et d'anticorps antifacteur II. I. Le facteur II chez les sujets traités par les antagonistes de la vitamine K. Thromb. Diath. haemorrh. 20: 89 (1968).

19 Nilehn, J.E. and Ganroth, P.D.: Plasma prothrombin during treatment with dicumarol. I. Immunochemical determination of its concentration in plasma. Scand. J.clin. Lab.Invest. 21: 17 (1968).

20 ReEkers, P.P.M.: Proteins induced by vitamin K absence in the cow; thesis, Leiden (1972).

21 Josso, F.; Monasterio de Sanchez, J., Lavergne, J. M., Menaché, D., and Soulier, J.P.: Congenital abnormality of the prothrombin molecule (factor II) in four siblings: prothrombin Barcelona. Blood 38: 9-16 (1971).

Request reprints from: Dr. A. GIRoLAMI, Institute of Semeiotica Medica, University of Padova Medical School, Padova (Italy) 